\title{
Technical Aspects of the Plutonium Vitrification Option (U)
}

by

J. Malvyn (Mal) McKibben

George W. Wicks

Westinghouse Savannah River Company

Savannah River Site

Aiken, SC 29808

A paper proposed for presentation at the American Nuclear Society National Meeting Panel Session on Plutonium Management Philadelphia, PA

June 26 - 29, 1995

The information contained in this article was developed during the course of work under Contract No. DE-AC09-89SR18035 with the U.S. Department of Energy. By Acceptance of this paper, the publisher and/or recipient acknowledges the U.S. Government's right to retain a nonexclusive, royalty-free license in and to any copyright covering this paper along with the right to reproduce, and to authorize others to reproduce all or part of the copyrighted paper. 


\section{DISCLAMMER}

This report was prepared as an account of work sponsored by an agency of the United States Government. Neither the United States Government nor any agency thereof, nor any of their employees, makes any warranty, express or implied, or assumes any legal liability or responsibility for the accuracy, completeness, or usefulness of any information, apparatus, product, or process disclosed, or represents that its use would not infringe privately owned rights. Reference herein to any specific commercial product, process, or service by trade name, trademark, manufacturer, or otherwise does not necessarily constitute or imply its endorsement, recommendation, or favoring by the United States Government or any agency thereof. The views and opinions of authors expressed herein do not necessarily state or reflect those of the United States Government or any agency thereof.

This report has been reproduced directly from the best available copy.

Available to DOE and DOE contractors from the Office of Scientific and Technical Information, P.O. Box 62, Oak Ridge, TN 37831; prices available from (615) 576-8401.

Available to the public from the National Technical Information Service, U.S. Department of Commerce, 5285 Port Royal Road, Springfield, VA 22161. 


\section{DISCLAIMER}

Portions of this document may be illegible in electronic image products. Images are produced from the best available original document. 
WSRC-MS-95-0200

\title{
Technical Aspects of the Plutonium Vitrification Option *
}

by

\author{
J. Malvyn (Mal) McKibben \\ George W. Wicks
}

Westinghouse Savannah River Company

Savannah River Site

Aiken, SC 29808

Vitrification of $\mathrm{Pu}$ and placement in a repository was one of two disposal options recommended by the National Academy of Sciences in a report issued in 1994 [1, 2].

Studies done at SRS and a review of international literature confirm that vitrification of surplus plutonium as borosilicate glass is a technically viable option. The technical basis for this conclusion derives in part from many decades of commercial production of this type of glass and the 30+ years of international development and use of borosilicate glass for stabilization of highlevel radioactive waste from reprocessing of spent fuels, which has gained wide international acceptance.

A variety of processes and types of equipment are in commercial use throughout the world, producing borosilicate glass for a variety of large and small commercial applications, both radioactive and non-radioactive. Most of these technologies could be adapted to produce plutonium borosilicate glass, with or without added fission products. Although there are many differences among these applications, including feed compositions, melter designs, scale (size), and heating methods, the compositions and properties of most of the final glass products are similar. Heating methods in common use include joule heating (heating by resistance to the flow of electricity through the molten pool), magnetic induction, microwave, plasma, and radiant energy from resistance heaters. All of these heating methods work, and the best choice depends on the particular application, the throughput that is needed, feed composition, and final form requirements. Vitrification of high-level and low-level radioactive wastes is now becoming commonplace world-wide.

Within the nuclear community, vitrification of high-level radioactive wastes has been studied for over three decades. The oldest and most thoroughly demonstrated process is the one that was used in France at Marcoule, which with minor alterations is being used in the United Kingdom, and France (LaHague). This process calcines acidic waste, feeding the dry calcine to the melter. In the U.S., most of the high-level radioactive wastes (Savannah River Site and Hanford) are alkaline, and contain significant quantities of sodium and aluminum. For vitrification of these wastes it was judged appropriate to use a liquid slurry-fed melter. Germany and Japan processes also plan to use liquid-fed melters. The melter in use at the Defense Waste Processing Facility (DWPF) at the Savannah River site (SRS) has joule and radiant heating. It also has a cooling

\footnotetext{
* The information in this article was developed during the course of work under Contract No. DE-AC09-89SR18035 with the U.S. Department of Energy.
} 
water jacket that freezes the glass in the interior insulation, which prevents molten glass from reaching the melter's steel shell and maintains the exterior at a low temperature to prevent up-drafts of contaminated air. To satisfy the need to demonstrate compliance with waste form criteria, this melter has the capability for sampling the molten glass as it pours from the melter into the canister.

Vitrification plants for high-level radioactive wastes are in commercial operation in France, the United Kingdom, and Belgium (with Germany), and will soon be operating in the, the U.S. and Japan. Vitrification plants for low-level waste are becoming commonplace. During the development of these technologies some data was obtained on the behavior of plutonium in this type of glass [3]. More recently, plutonium glasses have been studied, yielding sufficient data to increase confidence that plutonium can be safely and securely incorporated into a high-level waste glass at concentrations up to at least 4 to $5 \%[4,5]$ by weight, and at higher concentrations in glass without high-level waste components [6].

Specific technologies exist to vitrify plutonium as borosilicate glass, with or without added fission products or radioactive spiking materials. Vitrification without added fission products or radioactive spiking materials could be done in glovebox facilities with only modest shielding to protect the workers from the $0.060 \mathrm{Mev}$ gamma radiation from Am-241, the daughter of Pu-241. If the radioactivity from either high-level waste or separated Cs-137 were incorporated in the glass as a proliferation deterrent, the process would require heavy shielding, i.e., remote operations in large cell or canyon-like facilities.

Preliminary criticality studies indicate that a high quality borosilicate glass can be made without adding neutron poisons other than the boron and lithium that are inherent ingredients in the glass [1]. The boron and lithium in one of SRS's reference glasses would assure criticality safety up to about 14 weight $\% \mathrm{Pu}$. This amount of poisoning would be adequate for safe long-term vault storage, where no mechanism exists for separating the poisons from the $\mathrm{Pu}$. However, if the plutonium borosilicate glass were to be placed in a repository, nuclear criticality avoidance would a significant issue because of the potential over geologic time for leaching to separate the more soluble boron and lithium from the $\mathrm{Pu}$. Adding a rare earth neutron poison such as gadolinium, with chemistry more similar to the actinides, would reduce the risk of criticality over geologic time. The potential for long-term repository criticality from plutonium borosilicate glass and from $U$ and $\mathrm{Pu}$ in spent fuel is now being assessed by the technical community, but this issue is not yet resolved. Indeed, there is a session on that subject at this conference.

The chemistry of the plutonium glass-making process would require some additional laboratory development and demonstration for this application. For example, tests would be conducted to determine the optimum composition of the glass for this specific purpose. Properties of the glass product, such as durability and leach rates of plutonium and other components, must be determined. More detailed calculations and modeling of nuclear criticality safety must be made that include other glass compositions and poisons, a variety of neutron moderating conditions, and plutonium isotopic variations. The effects of other poisons on plutonium solubility and glass properties needs to be determined, as does the leach rate of other candidate poisons. The volatility and entrainment of plutonium into the melter offgas needs to be determined for candidate melter systems as a function of melter temperature, offgas flow rate, and other process and equipment variables. If any measurable carry-over of plutonium into the offgas is possible, the design must detect and prevent plutonium accumulations in the offgas system that could lead to nuclear criticality accidents. Design features must also assure that criticality cannot occur throughout the process, including in the melter feed tanks or in the melter itself. 
Vitrification of plutonium without added radiation sources may prove to be desirable regardless of whether or not national policies elect to retain the plutonium for its future energy production value or permanently dispose of it in a geologic repository. This form can be produced much faster, in existing facilities, than the form with fission products, and is a critically safe, stable, monitorable form. It could not quickly be converted to a weapon, so it would be advantageous for with safeguards and security. Yet, the plutonium in this glass could be recovered and purified for later use in reactor fuels when its energy value is higher and competitive with other energy sources. This recovery could be achieved using existing technology and facilities in any nation with nuclear capability, but would be more difficult in non-nuclear nations or by terrorist groups. On the other hand, if the U.S. or any other nation chooses to permanently dispose of its surplus plutonium in a repository with a radiation source, the plutonium glass (without radiation source) makes a nearideal feed for a vitrification process that would incorporate the high-level waste or Cs-137.

1. "Management and Disposition of Excess Weapons Plutonium", National Academy of Sciences Committee of International Security and Arms Control, National Academy Press, Washington, D.C., 1994.

2. "Vitrification of Excess Plutonium (U)", J. M. McKibben, et al, WSRC-RP-93-755, May 1993, Westinghouse Savannah River Company, Savannah River Site, Aiken, SC 29808.

3. "Development of Glass Compositions for Immobilization of SRP Waste", M. J. Plodinec, DP-1517, Savannah River Plant, February, 1979

4. "Incorporation of $\mathrm{Pu}$ and Other Actinides in Borosilicate Glass \& in Waste Ceramics", H. Matzke \& J. van Geel. NATO Advanced Workshop on Disposition of Weapons Pu Approaches and Prospects, St. Petersburg, Russia, May 14-17, 1995

5. "SRS Vitrification Studies in Support of U.S. Program for Disposition of Excess Pu", G. G. Wicks, J. M. McKibben, M. J. Plodinec, \& W. G. Ramsey. NATO Advanced Workshop on Disposition of Weapons Pu - Approaches and Prospects, St. Petersburg, Russia, May 14-17, 1995

6. "Compositions and Durabilities of Glasses for Immobilization of Plutonium and Uranium", W. G. Ramsey, N. E. Bibler, \& T. F. Meaker, Savannah River Site. Proceedings, Waste Management '95, Tucson, AZ, 1995 